\title{
Suomea kuvaamassa ja aistimassa
}

\author{
Mäkiranta, Mari, Ulla Piela \& Eija Timonen (toim.) 2017: Näkyväksi sepitetty \\ maa. Näkökulmia Suomen visualisointiin.
}

Helsinki: SKS.

\section{Sinikka Vakimo}

S uomen 100-vuotisjuhlavuonna Kalevalaseuran vuosikirja Näkyväksi sepitetty maa (2017) suuntaa katseensa suomalaisuuden rakentumiseen ja ajassa muuttuviin Suomi-kuvan tulkintoihin. Tätä laajaa perspektiiviä rajaa teoksen suuntautuminen suomalaisuuden visuaalisiin esittämistapoihin, mikä vähemmän tarkasteltuna näkökulmana herätti oman kiinnostukseni teokseen. Rajaus visuaalisiin "sepityksiin" suuntaa kokoelman kirjoituksia keskustelemaan pääosin taiteentutkimuksen, visuaalisen kulttuurintutkimuksen ja taidelähtöisen tutkimuksen kentillä. Tämä tuottaa inspiroivia mahdollisuuksia taiteen ja tieteen välisiin vuoropuheluihin ja metodisiin kokeiluihin visuaalisesta moniaistisuuteen, katsomisesta kokemukseen ja sen monisyiseen tulkinnallisuuteen, sekä näiden yhdistelmiin. Rajojen ylittämisiin ja metodisiin kokeiluihin kirjoittajia on arvatenkin kannustettukin, koska kirjan toimittajat Mari Mäkiranta, Ulla Piela ja Eija Timonen painottavat johdannossaan, ettei kirjan tarkoituksena ole tuottaa jähmeää ja yksimielistä kuvaa yhtenäiskulttuurisesta Suomesta, vaan paremminkin kehitellä uusia näkökulmia muuntuvaan ja moniääniseen, ristiriitaiseenkin suomalaisuuskuvastoon. Ajallisesti mukana on kuvauksia suomalaisuuden eritahtisista muotoutumisista Suomen itsenäistymistä edeltävältä ajalta aina nykyaikaan asti. Kerronnaltaan toiset analysoidut kuvaukset myötäilevät perinteistä kuvauskaanonia, toiset taas ovat sitä kiistäviä esittäen uudenlaisia määrittelyitä kansakunnan omakuvan sisälle ja sen ulkopuolelle asettuvista ilmiöistä.

Näkyväksi sepitetty maa -teos koostuu 17 artikkelista, jotka on laatinut yhteensä 24 tutkijaa kahdeksasta eri yliopistosta. Kirjan artikkelit on jaettu kolmen väljän teeman alle: muutos, liike ja kuviteltu. Muutos-osiossa tarkastellaan suomalaisessa luonto- tai kulttuuriympäristössä tapahtuneita historiallisia, yhteiskunnallisia ja kulttuurisia muutoksia, kun taas liike-osiossa keskitytään suomalaisiin kulttuuri-ilmiöihin ja niiden taustalla vaikuttaviin ajattelumalleihin ja ideologioihin. Kuviteltu-osiossa eritellään Suomen visualisointeja maailmalla ja maailmalle. Valtaosa teoksen kirjoittajista on taiteiden tutkimuksen alalta, monet myös taiteen tekijöitä, mikä tekee kirjasta erityisen kiinnostavan, sillä siinä kulttuurin- ja taiteentutkimuksen käsitteet ja lähtökohdat kytkeytyvät toisiinsa suomalaisuuden visuaalisuutta määrittävissä viitekehyksissä. Kirjan sivuilla vilahteleekin kuvitteellisen yhteisön, banaalin nationalismin ja keskusta-periferian tarkasteluiden lisäksi sukupuolen, rodullistamisen, 
luokkataustaisuuden, vallan ja määrittelyvallan tai vaikkapa affektin ja kuvattamisen käsitteet suhteutettuna kansallisen kontekstiin. Monipuolinen ja jännittävästi ennalta arvaamaton lukukokemus odottaakin kirjassa lukijaansa. Kirjan loppuosaan sijoitettu kuvaliite toimii hyvin kirjoitusten analyysi- ja tulkintaprosessin havainnollistamisen apuvälineenä ja ohjaa myös visuaaliseen luentaan tottumatonta lukijaa eteenpäin.

Kirjan artikkelit ovat pääsääntöisesti tutkimusartikkeleita kysymyksenasetteluineen, tutkimusaineistoineen ja viitekehyksineen poikkeuksena kaksi artikkelia. Näistä ensimmäinen on kirjan toimittajien laatima ansiokas johdantoartikkeli, jossa luodataan suomalaisuuden kuvastojen katsomis- ja tulkintatraditioita. Toinen on monissa kirjan artikkeleissa viitatun Kuvitettu maa -teoksen (2005) laatijan, Maunu Häyrysen informatiivinen artikkeli, jossa tarkastellaan kansallisen maisemakuvaston tutkimusta, pohditaan maisematutkimuksen muutoksia ja hahmotellaan uudenlaista, visuaalisen luennan ja sen kehollisen vuorovaikutuksen huomioivaa maisematutkimuksen otetta. Teoksen kirjoitukset ovat eri tavoin inspiroivia: osa kosketti jännittävällä tutkimusasetelmallaan tai aineistollaan, toiset metodisella kokeilullaan tai tulkinnallisella uutuudellaan. Lisäksi joitakin kirjoituksia lukiessa tuli yksinkertaisesti miellyttävä tuntu tekstin informatiivisuudesta ja siitä, että huomaa oppivansa uutta.

\section{Visuaaliset aineistot uudelleen luennassa}

Näkyväksi sepitetty maa -kirjassa on ilahduttavan monta kirjoitusta, joissa tutuilta tuntuvien visuaalisten aineistotyyppien analyysiin tuodaan uudenlaista käsitteistöä, näkökulmia tai aineistoluentaa. Lähes kaikissa myös luodataan suhteellisen pitkää aikaperspektiiviä, 1900lukua. Huolellisen aineistoanalyysin myötä kirjoituksista rakentuu jännittäviä läpivalaisuja kansallisuuden tematiikkaan; nämä kirjoitukset muodostavatkin käsillä olevan kokoomateoksen perusytimen. Päivi Granön, Lauri Kemppisen ja Anniina Koivurovan tulkitsemissa koululaisten kahtena eri aikakautena (v. 1947 ja 2016) piirtämissä kotien pihapiireissä hahmottuu se kulttuurinen ja yhteiskunnallinen muutos, joka on leimannut 1900-luvun Suomea. Toisaalta myös nykyajan pihapiirikuvauksissa löytyy viitteitä varhaiseen, maalaismaisemaa ihannoivaan kuvaustraditioon pihapiiriin sijoitettuina luonnonelementteinä. Myös kaupunki- ja tehdasympäristöjen sekä kerrostalopihojen vähäinen esiintyminen molemmissa aineistoissa voidaan nähdä kytkeytyneenä luontomerkitysten tärkeyteen. Kirjoittajat kuvaavat, kuinka kansakuntaa ja sen myötä myös kotia ja pihapiiriä rakennettiin esteettisenä projektina; sodanjälkeisenä kautena siirtymä luonnonmaisemasta rakennetun maiseman estetiikkaan toteutui tyyppitaloissa ja niiden pihapiireissä. Piirustuksissa aikakauden muutokset näkyvät siinä, mitä näiden rintamamiestalojen pihoilla kuvataan tehtävän: varhaisemmassa aineistossa pihat korostivat työntekoa, kun taas 2010-luvun kuvauksissa pihapiirit ovat värittyneet vapaa-ajan vieton elementeillä. Piirustusten oivaltavassa luennassa näyttäytyvät niin ajassa muuttuvat suomalaisen kodin, sivistyksen ja hyveiden ideaalimallit kuin lasten arkimaailman ja toisaalta myös piirustustaitojen muutokset ajassa.

Osittain samaan ympäristöön sijoittuu Jenny Pätärin ja Reijo Kupiaisen koulutaulujen Suomea visuaalisten järjestysten suunnasta analysoiva kirjoitus. Sen aineiston ensimmäiset opetustaulut sijoittuvat 1900-luvun alkuun, siis niin sanotulle sortokaudelle, jolloin koko opetustaulujen teon traditioon kiinnittyi sivistystehtävän ohella kansallisen identiteetin ja yhdenmukaisen suomalaisuuden esittämisen tehtävä, mikä puitteisti taulujen laatimista pitkälti myös tulevaisuuteen. Kirjoittajien mukaan koulutaulujen tuotannon periaatteena olikin yhteiskunnallisten epäkohtien poishäivyttäminen ja yhtenäiskulttuurin korostaminen, ja 
niissä näin ollen oli nähtävissä eri aikakausiin kytkeytyvät suomalaisen yhteiskunnan sosiaaliset jännitteet, poissulkemiset ja toiseuden tuottamisen prosessit.

Hieman toisenlaisessa, vaikkakin varsin tuttujen visuaalisten aineistotyyppien parissa liikutaan sekä Raija Talvion että Juha Ridanpään kirjoituksissa. Talvion tarkastelun kohteena ovat suomalaisen elokuvan heinäkasakohtaukset 1930-luvulta alkaen. Hän lukee niitä suomalaisuudesta kertovina, "kansallisina elokuvina" ja peilaa niitä suomalaisen elokuvan keskeiseen aihepiiriin, maaseudun ja kaupungin välisen eron ja jännitteiden problematiikkaan. Heinäkasakohtaukset eivät - ennakkokäsityksestä poiketen - olleet mitenkään yleisiä suomalaisessa elokuvassa, mutta niiden merkitys on ollut tärkeä kansallisen omakuvan rakentamisessa. Niiden kehystäminä voitiin käsitellä eri aikakausina ajankohtaisia jännitteitä ja luokkaristiriitoja, vahvistaa työteon eetosta ja pohtia kielletyn rakkauden ja laajemminkin moraalin kysymyksiä. Juha Ridanpään luennan kohteena taas on rajan ylittämisen geopolitiikka kahdessa eri aikakauteen sijoittuvassa elokuvassa ja se, miten kansallista identiteettikertomusta elokuvassa rakennetaan rajan ylityksillä. Kansalaisuus määrittyy Ridanpään mukaan 1930luvun rajaa kuvaavassa elokuvassa rotukysymyksinä saaden valtioiden rajat näyttäytymään keinotekoisina ja "luonnollista järjestystä" rikkovina. 1980-luvun Hollywood-elokuvassa taas peilautuu kylmän sodan jälkeinen "banaali geopoliitikka", vallitsevan maailmantilanteen vahvistaminen ja niin sanottuun suomettumiskeskusteluun liittyvä identiteettipolitiikka.

Suomi-kuvaa tarkastelevista artikkeleista Maija Mäkikalli käyttää jännittävästi pääaineistonaan Kirnua, Suomen paviljonkia Sanghain maailmannäyttelyssä, ja erittelee sitä ja siitä kertovia esittelytekstejä maakuvan visualisointina ja julkisuusdiplomatiana maailmannäyttelyiden kehyksessä. Tietoisen Suomi-kuvan rakentamisen prosessien erittelyihin kohdistuvista kahdesta artikkelista ensimmäisessä Leena-Maija Rossi pyrkii purkamaan kansallisen käsitettä ja tarkastelee maakuvan rakentuneisuutta "kuvattelun koneena" (de Lauretis1984) soveltamalla intersektionaalisen sukupuolentutkimuksen mukaisia näkökulmia Suomen virallisten tahojen tuottamiin materiaaleihin. Kaisa Hiltusen, Tuija Saresman, Nina Sääskilahden ja Antti Valliuksen artikkelissa taas nojaudutaan maabrändiviestinnässä aina 1800-luvun lopulta alkaen käytettyihin kuva-aineistoihin ja fokusoidutaan kuvissa peilautuviin hierarkkisiin ja hierarkisoiviin eroihin ja niiden muutoksiin.

\section{Uusia avauksia}

Valokuvan tulkinnallisilla kehillä liikkuvat riemukkaan keveästi, mutta teoreettisesti informoidusti Mari Mäkiranta ja Eija Timonen lukiessaan affektiivisesti ja moniaistisesti dokumenttivalokuvaaja Laura Böökin (2016) laatimaa valokuvaa. Se kuuluu osaksi teossarjaa, jossa kuvataan Pudasjärvelle muuttaneiden ja sitä ennen viisitoista vuotta pakolaisleireillä viettäneiden pakolaisperheiden elämää. Tarkastellun kuvan keskiössä on kaksi kongolaista naista talvisella maantiellä, enemmän tai vähemmän talviseen säähän sopivissa vaatteissa. Kirjoituksessa eritellään kiinnostavasti kuvan moniaistisen tulkinnan metodisia mahdollisuuksia, valokuvan herättämää "affektiivista värähtelyä" ja viime kädessä niitä (kansallisuuteen) kuulumisen ja ulossulkemisen tapoja, jotka kuvaan ja sen tulkintakonventioihin ovat asettuneet. Kirjoitus vakuuttaa moniaistista tulkintametodia epäilevät metodisella selkeydellään: moniaistisuudesta voi kirjoittaa näinkin ymmärrystämme lisäävästi.

Kokemuksellisuus, kokeilevuus, itsereflektio ja moniaistisuus ovat läsnä joissakin taiteilija-tutkijoiden kirjoituksissa, joissa hienosti välittyy tekemisen kautta tuotetun tiedon 
erityisyys. Näistä metodiselta otteeltaan virkistävän kokeilevista - joskin kirjan teemaan ehkä väljemmin kytkeytyvistä - kirjoituksista on mainittava Annette Arlanderin itsereflektiivinen, autoetnografiaa lähenevä tarkastelu kahdentoista vuoden mittaisen videoteossarjan Animal Years kuvauspaikasta Harakan saarella Helsingin kupeessa. Kyseessä on eräänlainen maisemaseuranta, jonka tuotoksia, kahtatoista näkökulmaa maisemaan, Arlander pohtii posthumanistisen ja uusmaterialistisen viitekehyksen valossa. Silja Nikulan kirjoituksessa taas pohditaan puuta piirtäjän materiaalina ja puuhun liittyvien kulttuuristen mielikuvien siirtymistä taideteoksissa näkyvään muotoon. Hänen tulkintansa nojautuu tekijän näkökulman lisäksi teoreettiseen keskusteluun kuvan kerronnallisista keinoista. Myös kuvataiteilija ja maisteriopiskelija Kristian Tuomaisen moniaistista tietämistä ja laavuestetiikkaa tarkasteleva kirjoitus nojautuu vahvasti omaan, monisyiseen ympäristökokemukseen.

Lopuksi on vielä mainittava kaksi itselleni erityisen opettavaista kirjoitusta, joista Hanna Johanssonin kirjoitus hätkähdytti kiehtovalla tutkimusotteellaan hänen tarkastellessa eläinten esittämisen muutoksia suomalaisessa kuvataiteessa 1800-luvulta nykyaikaan asti. Näitä muutoksia hän lähestyy kahdesta näkökulmasta: kuvaamisen uusien tekniikoiden ja kulttuuristen arvostusten siirtymisen sekä eläimestä saatavan tiedon muutoksista johtuvista suunnista. Historiallisena aineistona hän käyttää Magnus von Wrightin ja Jussi Mäntysen tuotantoa ja työtä taitelijoina ja tutkijoina; uudempaan, vertailevaan aineistoon on otettu joitakin nykytaiteen eläimiä esittäviä teoksia. Johansson lukee yksittäisiä lintu- ja eläinteoksia hienovaraisesti ja niiden syntyajankohdan taiteen tavoitteita ja ilmaisutapoja lukijalle avaten. Mäntystä ja von Wrightiä tarkastellaan tieteilijöinä ja eläinten käyttäytymisen seuraajina ja tietysti myös taiteilijoina taksidermisen - eli lintujen täyttämiseen perustuvan taiteen - valossa. Kirjoituksesta piirtyy hieno kaari taksidermian eri suuntauksista ja niiden sidoksisuudesta teknologian ja tieteen edistysaskeliin sekä niiden kytkennästä eläinten esittämisen traditioihin ja päämääriin eri aikoina.

Toinen monia oivalluksia tarjonnut artikkeli on Jyrki Siukosen kirjoitus ilmakuvauksista ja kansallisen maiseman murtumista ilmakuvien analyysissa. Aineistonaan hän käyttää neljää ilmakuvakirjaa vuosilta 1928-1959 ja vertailuaineistona kahta, vuosina 2007 ja 2008 ilmestynyttä ilmakuvakirjaa sekä kuvauksia lentämisen vaikutelmista. Siukonen lukee kirjojen kertovan eri aikoina ennen kaikkea siitä, mitä Suomesta pitää nähdä: ilmakuvakirjojen traditiossa on sekä vakiintuneita kuvaustapoja ja -kohteita että myös näiden poikkeamia ja ulossulkemisia. Jo Topelius markkinoi Punkaharjun kauneutta Maamme kirjassaan (1876) ja Punkaharjusta muodostuikin yksi tärkeistä varhaisen, elitistisen turismin kohteista Suomessa. Topelius katseli maisemaa maan pinnalta, "kylätien perspektiivistä", mutta ilmasta katsottuna ihanainen Punkaharjukin saattoi näyttää "jokapäiväisen sulottomalta", kuten Siukonen kertoo lentäjä Chansonin tätä talvipäivänä kuvanneen 1920-luvulla. Lentäminen mahdollisti avarien näkymien taltioimisen ilmakuvissa, minkä lisäksi siinä kiehtoi liikkeen ja vapauden tuntu. Ilmakuvatraditiota voikin tarkastella tietynlaisesta runollisesta, kansakuntaa eheyttävästä suunnasta, varsinkin kun kuvauskohteisiin ei koskaan eksynyt esimerkiksi Tammisaaren pakkotyölaitoksen kaltaisia säröjä, kuten Siukonen kirjoittaa. Hän pohtii myös oivaltavasti erilaisten poikkeamien ilmaantumista kuvastojen kerrontaan. Tällaisina voi mainita esimerkiksi Lapuan kirkonkylän ilmaantuminen 1930-luvun teoksen ilmakuviin, vaikka Pohjanmaata ei yleensä kirjoissa kuvattu, sekä sen, että suurin osa Suomen maasta itsestään jäi teoksissa kuvaamatta: suoalueet ilmaantuivat teoksiin verraten myöhään. 
Kaikkiaan Näkyväksi sepitetty maa onnistuu tuottamaan virkeitä, niin aiempia käsityksiämme vahvistavia kuin niitä säröttäviäkin läpivalaisuja suomalaisuuteen. Vaikka on selvää, että tällaisessa temaattisessa artikkelikokoelmassa on aina väistämättä kirjoituksia, joiden kytkentää kirjan teemaan on paikoin vaikea havaita, tulin joidenkin kirjoitusten kohdalla miettineeksi, että niiden pois jättäminen olisi vahvistanut teoksen punaisen langan näkymistä nykyistä selvemmin. Kiinnostavia ja hyvin laadittuja teoksen kaikki kirjoitukset kyllä ovat.

\section{Kirjallisuus}

de Lauretis, Teresa 1984: Alice Doesn't. Feminism, Semiotics, Cinema. London \& Basingstoke: Macmillan.

Häyrynen, Maunu 2005: Kuvitettu maa. Suomen kansallisen maisemakuvaston rakentuminen. Helsinki: SKS.

Topelius, Zacharias 1876: Maamme kirja.

Filosofian tohtori Sinikka Vakimo toimii tällä hetkellä tutkijana Koneen säätiön rahoittamassa tutkimushankkeessa Normaalin rajoilla. Dementian ja vanhuuden kulttuuriset merkitykset suomalaisessa ja venäläisessä kulttuurissa Itä-Suomen yliopistossa. 